BACTERIOLOGICAL NOMENCLATURE AND T AXONOMY

\title{
THE NOMENCLATURE OF THE BACTERIUM FOUND IN GRANULOMA VENEREUM
}

\author{
Otto G. Bier
}

Dept. of Immunology, Instituto Biológico, Sła Paulo, Brazil

Aragão and Vianna(1) in 1913 in a study of 8 cases of granuloma venereum confirmed the existence of the so-called "Donovan bodies" (2) and interpreted them as bacteria related to Friedländer's bacillus. They proposed the name Calymmatobacterium granulomatis for the organism. In three of the eight cases an encapsulated rod was isolated from cultures of the lesions and its etiological relationship to granuloma venereum discussed by the authors. The authors expressed doubt as to the specificity of the bacteria cultured because they grew readily on ordinary media and were cultivated in only three cases, even though all lesions showed large numbers of Donovan bodies on microscopic examination.

In 1917 (3), Aragão refers to 5 more cultures obtained by Dr. H. de Souza Araujo and emphasizes once again that the etiological significance of the cultivated bacterium could only be established by further research. In a paper presented to the lst Brazilian Congress of Dermatology and Syphilology in October 1918 and published in March 1919 (4), Dr. Aragão states that he has isolated Friedländer-like organisms from 3 out of 20 normal urines, as well as from material from cases of rhinitis. He discusses the negative value of the isolation of such organisms, even from closed lesions (as in the case of Dr. Araujo's cultures) since there is always the possibility of an interchange of organisms be tween closed and open lesions. He compared the situation with whathas bee: =Lserved in leprosy, from which material only saprophytic mycobacteria are commonly isolated that ought not to be confused with the true Hansen's bacillus. The latter has not yet been cultivated.

The conclusions reached by Aragão in his paper published in 1919 are the following: 
1. The true microbe of granuloma venereum is the one described in 1905 by Donovan to which the name Galymmatobacterium granulomatis Aragăo and Vianna 1912 had been given, on account of its morphology, staining properties, mode of reproduction and parasitism.

2. Calymmatobacterium granulomatis had not yet been cultivated.

3. The microbes isolated from cases of granuloma venereum are not identical with the ones seen inside the cells in granuloma lesions, although similar to them in their morphology and staining properties.

4. The cultures obtained from cases of granuloma venereum are from capsulated bacteria of the Friedlander group whichare commonly found in the human body and do not produce lesions like those produced by Calymmatobacterium granulomatis.

5. It seems highly probable that the bacteria cultivated from cases of rhinoscleroma are also not identical with the characteristic microbes seen in the tissues in cases of that disease. The capsulated bacteria easily isolated from ozena cases also do not seem to be the agents of this disease.

It was clear to Dr. Aragão in 1918 that the name C a ly m matobacterium granulomatis should be applied only to the Donovan bodies and not to the accessory Kle bsi e 11 a - like organisms which had been isolated from granuloma lesions.

In spite of the clearness of these statements, Bergey in the first idition of Bergey's Manual (5) describes the encapsulated bacterium found by Aragão and Vianna in lesions of granuloma venereum under the name Encapsulatus inguinalis. Unfortunately $\mathrm{Calymmatobacterium}$ g $\overline{\text { ra }}$ nulomatis $A$. and V. was given as a synonym. This confusion was further increased in the second edition where the name of the Friedländer-like organism isolated was changed to Klebsiella granulomatis with Calymmatobacterium granulomatis A. and V. still listed as a synonym. 
Aragão, in $1933(6,7)$, criticizes this ascription andwiselv suggests the recognition of 2 genera in the tribe Kle bsielleae, the genus Klebsiella to include Friedländer's bacillus, and the genus Calymmatobacterium. The latter is to be reserved for intracellular parasites united in zooglea-like masses, not cultivable, producing cutaneous and mucous ulceration such as in granuloma venereum. These statements were not, however, taken into consideration by Chapman who prepared the section covering the granuloma venereum organism in the last (6th) edition of Bergey's Manual (8). In this he suppressed all descriptions of species of $\mathrm{K} 1 \mathrm{ebs}$ ie $11 \mathrm{a}$ except that of Friedländer's bacillus, merely listing other described species in an Appendix to the genus under the caption "The evidence for differentiating them into distinct species is so meager that for the present it may be better to consider them as varieties of Klebsiella pneumoniae." In this appendix Klebsiella granulomatis Bergey et al. is still listed as a synonym of Calymmatobacterium gra nulomatis A. and V. and the organism is listed as in previous editions as isolated "from granuloma inguinale". The new name given to Donovan bodies by Anderson, De Monbreun and Goodpasture (9) - Donovania granulomatis - is used and the organis $m$ is placed in the genus Donovania in an appendix to the tribe Pasteurelleae.

Thus Calymmatobacterium granulomatis A. and $V$. is made to appear as if this species was based on the cultures that they isolated and cultured from lesions of granuloma vereneum, although as indicated above Aragão and Vianna differentiated between the organisms found intracellularly (Donovan bodies) and the cultured organisms that resembled Friedländer's bacillus. There is no doubt in my mind that the species name Calymmatobacter ium granulomatis A. and V. has priority.

The inclusion of this species in an appendix to the tribe Pasteurelle ae also appears unjustified, so much more so since the work of Rake et al. $(10,11)$ shows by means of the electron microscope, not only the morphological similarity between Donovan bodies and Friedländer's ba- 
cillus but also the antigenic relationship between them.

\section{Summary and Conclusions}

Evidence is presented showing that $\mathrm{Calymmatobacter}$ ium granulomatis Aragão and Vianna, 1913 is the cor rect name for the agent of granuloma venereum. The genus Calymmatobacterium Aragão and Vianna should be listed as a genus coordinate with $\mathrm{K} 1 \mathrm{e} \mathrm{b}$ s ie $11 \mathrm{a}$ Trevisanin the Tribe Klebsielleae of the family Enterobacter iaceae.

Acknowledgment. The kind interest shown by Dr. R. S. Breed in the preparation of this paper is gratefully acknowledged.

1. Aragão, H. de B. and Vianna, G. Mem. Instituto Oswaldo Cruz, 5, 211-238, 1913.

2. Donovan, C. Indian Medical Gazette, 40, 414, 1905.

3. Aragão, H. de B. Transactions of the American Society of Tropical Medicine, in New Orleans Med. and Surgical Journal, 11, 26-31, $1 \overline{917 .}$

4. Aragăo, H. de B. Brazil Medico, pages 74-76, 1919.

5. Bergey, D. H. in Bergey's Manual of Determinative Bacteriology, 1st Edition, Williams and Wilkins, Baltimore. 1923, 238, 2nd Edition, 1925, 264.

6. Aragão, H. de B. Brazil Medico, pages 473-475, 1933.

7. Aragão, H. de B. Apropos du Calymmatobacter ium granulomatis et des Klebsiella. C.R. Se ances d. 1. Société de Biologie. Paris. 104:841-842. 1933.

8. Chapman, O. D. in Breed, R. S., Murray, E. G. D. and Hitchens, A. P., Bergey's Manual of Determinative Bacteriology, 6th Edition, Williams and Wilkins, Baltimore, pages 459 and 559. 1948.

9. Anderson, K. , De Monbreun, W. A. and Goodpasture,E. W., J. Exp. Med., 81, 25-38. 1945.

10. Rake, G. W. and Oskay, J. J., J. Bact., 55, 667-675. 1948.

11. Rake, G. W., Am. J. Syph. Gonorrhea and Ven. Dis., 32, 145-149. 1948. 